\title{
Examining the desired gender equality, the fifth goal of the UNESCO 2030 document from the perspective of jurisprudence and law with emphasis on the age of marriage and the right to divorce
}

\section{Examinar la deseada igualdad de género (quinto objetivo del documento de la UNESCO 2030) desde la perspectiva de la jurisprudencia y el derecho con énfasis en la edad para contraer matrimonio y el derecho al divorcio}

\author{
OmolBanin Ali Bakhshzadeh \\ PhD Student, Department of Theology, Mashhad Branch, Islamic Azad University, Mashhad, \\ Iran \\ ORCID: https://orcid.org/0000-0002-9437-5932 \\ Moloud Garmroudi Sabet \\ Assistant Professor, Department of Theology, Mashhad Branch, Islamic Azad University, \\ Mashhad, Iran \\ ORCID: https://orcid.org/0000-0002-6697-4313 \\ Ozra Entekhabian \\ Assistant Professor, Department of Theology, Mashhad Branch, Islamic Azad University, \\ Mashhad Iran \\ ORCID: https://orcid.org/0000-0002-1952-3827
}

*Correspondence

Email: m.garmroudi@gmail.com
Cite as:

Bakhshzadeh, O., Garmroudi, M., \& Entekhabian, O. (2021). Examining the desired gender equality, the fifth goal of the UNESCO 2030 document, from the perspective of jurisprudence and law with emphasis on the age of marriage and the right to divorce. Propósitos $y$ Representaciones, 9 (SPE2), e959. Doi: http://dx.doi.org/10.20511/pyr2021.v9nSPE2.959 
Examining the desired gender equality, the fifth goal of the UNESCO 2030 document, from the perspective of jurisprudence and law with emphasis on the age of marriage and the right to divorce

\section{Summary}

The purpose of this article is to examine the equality of women in the fifth goal of the 2030 document from a jurisprudential and legal perspective. The 2030 document is an international document that in recent years has raised important issues regarding its acceptance and nonacceptance. However, no independent and comprehensive research has been conducted on the implementation and comparison of this document with Islamic and legal standards. The present article is a descriptive-analytical and examines the question using the library method. The UNESCO 2030 document has several objectives, the fifth of which is dedicated to women. This goal has 9 goals that can be explained in two basic pillars and axes; 1 - Gender equality and 2Empowering all women and girls. The results of the article indicate that the 2030 document on the equality of women in many cases is in conflict with religious teachings and legal provisions regarding women in Iran. The first conflict goes back to the concept of equality. Equality in jurisprudence and law refers to the natural differences in the creation of men and women, but the 2030 document emphasizes the equality of men and women. The themes and criteria related to the age of marriage for women and the hijab for women in the 2030 document are in conflict with the jurisprudential and legal standards in Iran.

Keywords: 2030 document, UNESCO, Islam, women, Convention on the elimination of discrimination against women.

\section{Resumen}

El propósito de este artículo es examinar la igualdad de las mujeres en la quinta meta del documento 2030 desde una perspectiva jurisprudencial y legal, el documento 2030 es un documento internacional que en los últimos años ha planteado cuestiones importantes en cuanto a su aceptación y no aceptación. Sin embargo, no se ha realizado ninguna investigación independiente y exhaustiva sobre la implementación y comparación de este documento con los estándares islámicos y legales. El presente artículo es de tipo descriptivo-analítico y examina la pregunta utilizando el método de biblioteca. El documento UNESCO 2030 tiene varios objetivos, el quinto de los cuales está dedicado a las mujeres. Esta meta tiene 9 metas que se pueden explicar en dos pilares y ejes básicos; 1- Igualdad de género y 2- Empoderar a todas las mujeres y niñas. Los resultados del artículo indican que el documento de 2030 sobre la igualdad de la mujer en muchos casos está en conflicto con las enseñanzas religiosas y las disposiciones legales sobre la mujer en Irán. El primer conflicto se remonta al concepto de igualdad. La igualdad en la jurisprudencia y el derecho se refiere a las diferencias naturales en la creación de hombres y mujeres, pero el documento de 2030 enfatiza la igualdad de hombres y mujeres. Los temas y criterios relacionados con la edad para contraer matrimonio de las mujeres y el hijab para las mujeres en el documento de 2030 están en conflicto con las normas jurídicas y jurisprudenciales de Irán.

Palabras clave: documento 2030, UNESCO, Islam, mujeres, Convención para la eliminación de la discriminación contra la mujer.

\section{Introduction}

The 2030 education program, transnational programs and global unit versions to achieve the fourth goal of the UNESCO sustainable development goals; Inclusive development of the education system at all levels of education, including formal, non-formal and non-formal structures, to achieve a learning and sustainable society. The goal of the 2030 education program is to "ensure quality, equal and inclusive education and to promote lifelong learning 
opportunities for all". To achieve this goal, UNESCO has designed 7 specific objectives. These goals are: elementary and intermediate education; Development of early childhood care and preschool and inclusive education; Equal access to higher education and technical and vocational education; Different skills for a decent and honorable job; Equal learning and access for educational opportunities for men and women; Inclusive youth literacy; and citizenship education for sustainable development. But the necessary tools to achieve the above ideals are: 1. Development of a suitable learning space; 2. Increasing scholarships and teacher training; 3. Development of international cooperation (Jeffrey 2005, p 13).

The 2030 educational document or program has been compiled by the UNESCO National Commission and has been localized in various countries, including Iran. The document localized in Iran, as a "national document of education" is proposed and consists of seven parts: 1. Introduction; 2. Review of socio-economic and demographic indicators of Iran and its relationship with education; 3. Introducing the educational structure of Iran (from basic to higher); 4. Structure and macro-strategies of the 203 education program in the Islamic Republic of Iran; 5.7 goals of education; 6. Effective factors in achieving the goals of 2030 education; 7. Monitoring and evaluation system of the training program 2030. In Iran, this document is approved by the cabinet to form a working group; No. 52913/76403 dated 9/15/2016; Formation of 30 works of the national group focusing on the ministries; "The drafting of the" national education document 2030 of the Islamic Republic of Iran "was implemented by the working groups".

According to the goals announced by the United Nations, from 2015 to 2030, all member states of the United Nations should strive to achieve the goals and indicators of sustainable development through cooperation and interaction in the three national, regional and international levels. The statement on the agenda was entitled "Transforming Our World: A 2030 agenda for sustainable development". This statement has 91 articles and includes 17 main objectives $^{1}$ and several sub-objectives. In fact, in order to achieve the goals of sustainable

development, the United Nations has set and approved these 177 grand goals, and all international specialized agencies, such as UNESCO, are committed to formulating their medium- and long-term strategies accordingly. Establishing gender equality and empowering all women and girls is an important pillar of the fifth goal of the 2030 UNESCO document.

The focus of this article is on gender equality and its goals in the 2030 document. The axes and partial goals mentioned in the fifth goal in the 2030 UNESCO document in order to create gender equality can be explained in the form of the following goals; Eliminate all forms of discrimination against women and girls everywhere; Eliminate all harmful behaviors and traditions, including forced marriage and control of land and other forms of property, financial services, and inheritance. This chapter examines the goals of achieving gender equality from the perspective of jurisprudence and law.

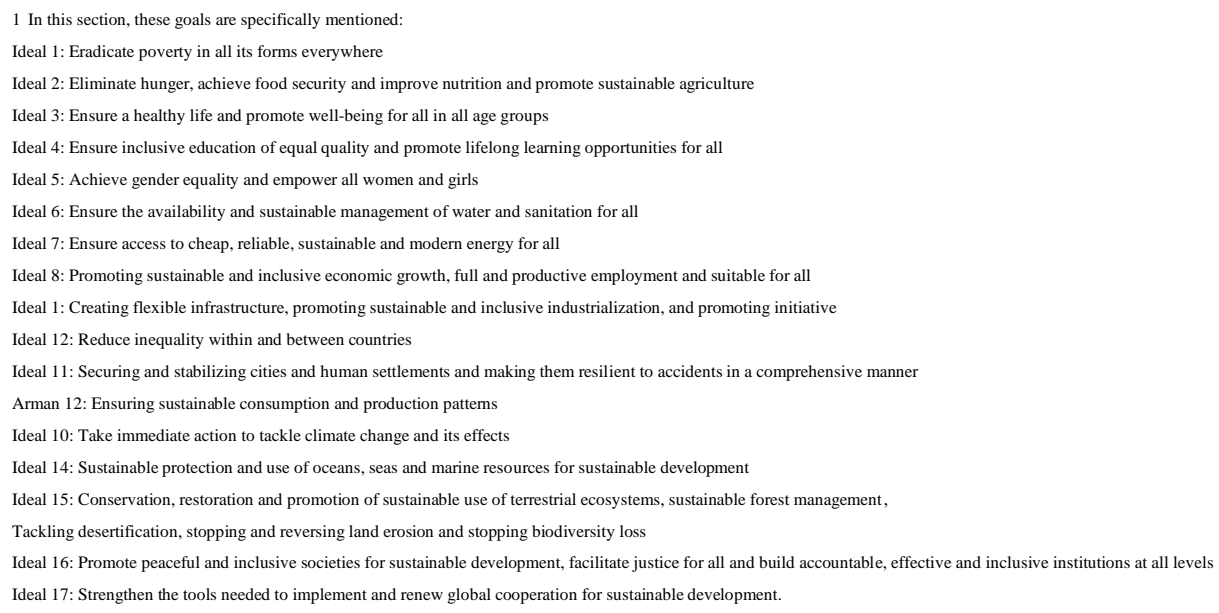


Examining the desired gender equality, the fifth goal of the UNESCO 2030 document, from the perspective of jurisprudence and law with emphasis on the age of marriage and the right to divorce

\section{The concept of equality in jurisprudence and law and the 2030 document}

\section{Equality in jurisprudence and law}

The religion of Islam equates all human beings and explicitly denies all the pride, racial

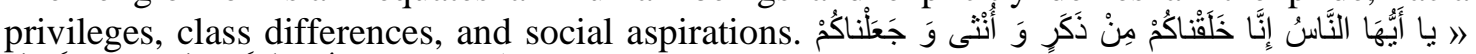

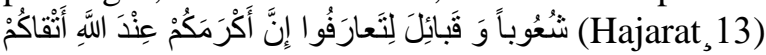

O people, we created you all from man and woman in the first then we made many different branches, that you might know one another, indeed, the most honorable and proud of you in the sight of God are the most pious of you. Indeed, Allah is All-Knowing, All-Aware".

This attitude of Islam towards human beings and the behavior of the Prophet (PBUH) based on it, attracted many to Islam. During the conquest of Mecca, when Bilal was commissioned by the Prophet to recite the call to prayer on the Ka'bah, many polytheists criticized the Prophet (pbuh) because of his skin color and slavery. As Atab ibn Asid ibn Abi Ayes said: Thank God that my father died and is not there to see this day and Harith ibn Hisham also continued: Muhammad did not find any other muezzin except this black crow and Sohail Ibn Amr said: When God wills something to change, Abu Sufyan added: I do not say anything; For I fear that the Lord of heaven may inform him; So Gabriel descended on the Prophet (PBUH) and informed him of what had happened, the Prophet (PBUH) summoned them and asked them what they had said, and they also confessed, after this fault finding them on the muezzin of the Prophet (PBUH), the above verse was revealed and declared all human beings equal and he forbade pride and storing wealth and belittling the poor, and considered the basis and criterion of human superiority over each other only the degree of piety and virtue ${ }^{2}$. Therefore, all human beings are from the same principle and root, and this unity and oneness of human beings is the basis and criterion of their equality and parity.

In Islam; Equality of value between men and women, as well as the same way of advancement for the two, is a fundamental principle and is considered one of the indisputable religious

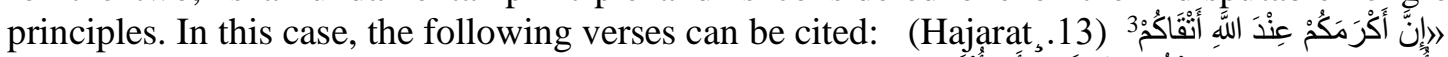

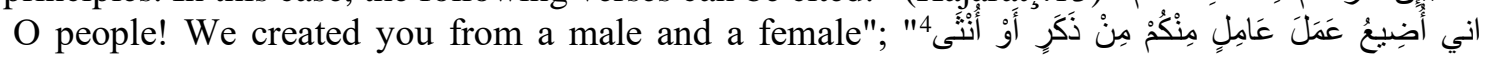
(Nahl/.97)

Of course, I do not waste the actions of any man or woman"; Whoever does a good deed, whether male or female, while we are believers, we

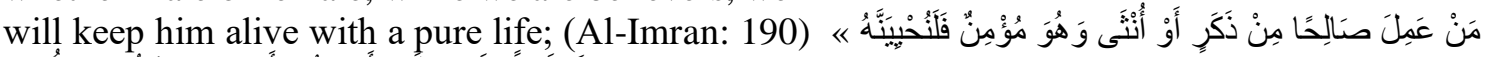

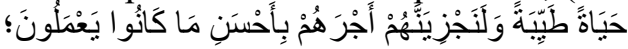

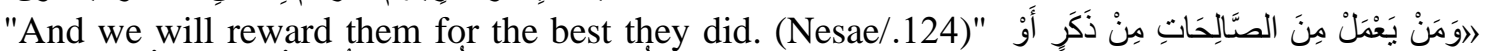

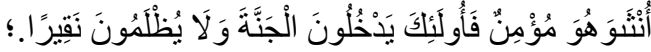

And those who do good deeds, whether they are men or believers, they will enter Paradise and will not be wronged as much as behind a palm kernel".

These verses express the equal rights of men and women. In these verses, man and woman are mentioned together, but these two beings are naturally and physically different. These differences necessitate the division of responsibilities and the training of social systems.

As an interpretation of the mentioned verses, it should be said that; the message of these verses, including verse 124 of Surah An-Nisa ', is as follows;

1. The cause of entering Paradise is faith and righteous deeds, not race, claims and desires. The

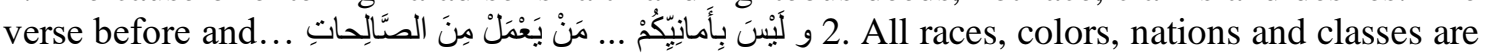

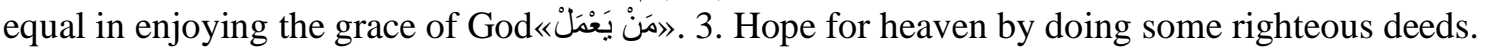

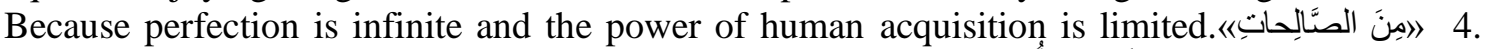

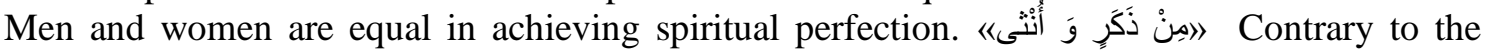
beliefs of a group of Jews and Christians. 5. Faith is a condition for accepting deeds and the services of unbelieving people are compensated in this world and have no afterlife value. مَنْ بَعْمَلْ 7. Good deeds,

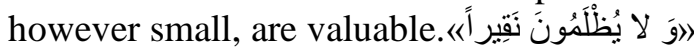




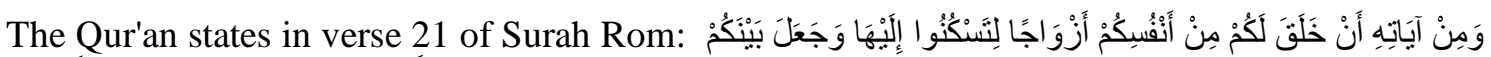

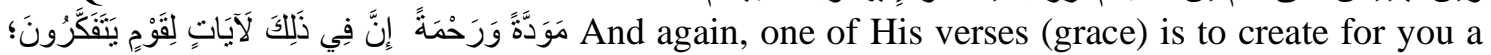
pair of your own kind that you will rest with him and get along with him, and he will establish compassion and kindness between you. In this, too, there are obvious proofs (from the knowledge and wisdom of the truth) for thoughtful people. The Qur'an says in the verse about the creation of the two: One of the signs of God is that we have created for you mates from among yourselves, which you may find comfort in them and friendship and kindness between you are signs for thinkers in this matter.

In interpreting the above verse, the following points can be mentioned; 1 - Creation is purposeful. «خَلَفَ لَكُمْن 2- Men and women are of the same gender. (Contrary to some superstitious and degrading beliefs that women are considered inferior or another gender).

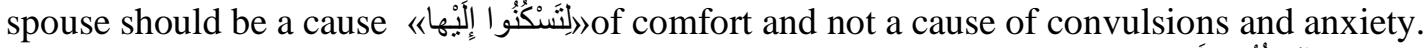

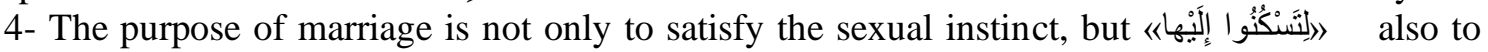
achieve a physical and mental peace.

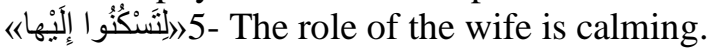

6- Love is a divine gift that cannot be obtained with wealth, status and beauty. "Forgery" (grace and mercy are God's gift to the bride and groom.) 7- Anyone who violates the peace, kindness and mercy of the family with any action is out of the divine orbit and in the line of Satan.

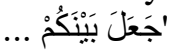

8- The relationship between a man and a woman should be based on time and mercy.

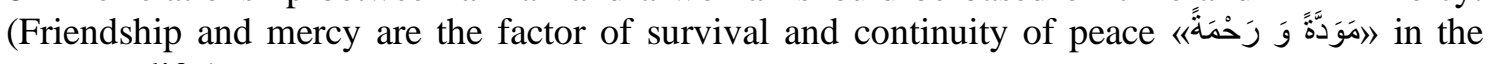
common life.)

9- Compassion and mercy both work together. (Compassion without mercy and service is drawn

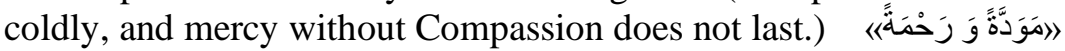

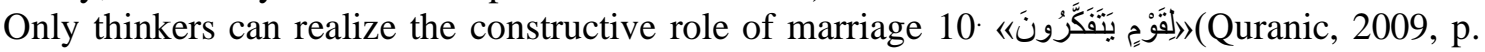
190.)

It has also been said that in terms of Islamic law, each of these two classes (men and women) has responsibilities for themselves that they can have a common share in forming a family and preventing its disintegration - which is the basis of society. But in Western culture, this is why women have been made men today, but they have not been able to make men look like women, the number of family system disintegrations in the world (West) is increasing every day and one of the consequences of the disintegration of the family is the futility of life and the alienation of human beings from each other. (Jafari, 1987, p.160)

The twentieth principle of the constitution was based on the twenty-second principle of the draft: "All members of the nation, men and women, are equal against the law" ( General Department of Laws of the Islamic Consultative Assembly 1985, p.76)

The discussion of this principle in the Assembly of Constitutional Experts took a little longer. What sparked some controversy was the controversy over whether the word equals rights or privileges or it refers to equality against the law otherwise, there is no substantive and conceptual controversy about the principle itself.

The principle of equal rights for men and women in the draft constitution was: "All members of the nation, both men and women, are equally protected by the law and enjoy full political, economic, administrative, civil, social and cultural rights in accordance with the rules of Sharia, which are commensurate with the natural, emotional and spiritual talents and backgrounds of each". The Vice President of the Assembly of Experts suggested that the phrase "Is located" should be changed to "Are located" to be a complete phrase.

\section{Natural differences in the creation of men and women}

The natural differences between men and women are undeniable, although there may be no consensus on the extent of these differences and the extent to which they affect to set the rules and regulations governing them. What is certain is that these differences are such that they can justify many of the differences between the rulings of men and women, as Martyr Motahhari has tried to answer some doubts about the system of women's rights in Islam through these differences, in response (Motahari,1991,190) to those who consider the belief in the difference between men and women to be medieval thinking, he says: "In the twentieth century, with the 
astonishing advances in science, the differences between men and women have become clearer and certain, it is not forgery, it is scientific and experimental facts. But these differences are in no way related to the fact that a man or a woman is of the superior gender and the other is not a lower, inferior and imperfect gender, the law of creation had another meaning for these differences. The law of creation has created the differences between men and women in a way similar to the meaning of differences between the organs of a body... In the new world, with indepth medical, psychological, and social studies, he has discovered more and more differences between men and women that were not realized in the old world at all (Motahari, Previous, p. 200).

\section{Human nature and the sharing of men and women in enjoying it}

The enlightening point that can be deduced from the divine verses is that gender characteristics are such that they do not distort the human sharing of men and women.

In verse 34 of Surah An-Nisa, which has already been discussed, it is stated that men are the protectors and householders of women, because of the advantages that God (in terms of the social system) has bestowed on some over others, and because of the alms they make of their property (in the case of women). And righteous women are women who are humble, and in the absence of (their husbands) keep their secrets and rights, in exchange for the rights that God has given them. And warn those women whom you fear of rebellion and opposition, and if it does not work, stay away from them in bed! And if there is no way other than the intensity of action, to force them to perform their duties, punish them, and if they follow you, do not seek a way to violate them! God is exalted and great. And his power is the highest power.

Of course, it is stated that proving the difference between men and this verse is not complete. It should be said that differences can be depicted in different ways. Regarding the differences between men and women in different dimensions, it may be said that their differences are in existence and non-existence, that is, for example, in the psychological structure of women, an element is used that does not exist in men, and vice versa; The implication of this statement is that the mentioned feature on both sides has no effect on humanity and is not considered a human element; Because otherwise the sharing of man and woman in human reality is disrupted.

\section{Equality from the perspective of the 2030 document; Convention forbidding discrimination against women}

Equality is not defined in the 2030 document, but given that the 2030 document is an updated form, it is another international document in the field of women's rights, to explain the concept of equality from the perspective of this document, we can refer to the convention on the elimination of all forms of discrimination against women. The preamble to that convention also states; It is believed that the full and complete development of a country, global prosperity and the establishment of peace, requires the integrated participation of women in all fields on an equal footing with men...... Recognizing that the role of women in reproduction should not be the basis of discrimination, but the upbringing of children requires the division of responsibilities between men and women and society in general, and change in the traditional role of men and women in society and the family is essential to achieving full equality between men and women.

Article 1 of the Convention defines discrimination as follows: "The term discrimination against women in this Convention refers to any discrimination (with the exception of restriction) on the basis of gender, which the result is to damage women's enjoyment of human rights and fundamental freedoms in the political, economic, social, cultural, civil, or any other field..." In this article, the Convention aims to establish full equality between men and women and to eliminate any discrimination against women, hence, it does not address discrimination in favor of women. In this international document, any difference between men and women in rights and duties is considered discrimination, however, those differences are the result of the developmental differences between men and women. This interpretation and attitude leads to equality of rights between men and women.

The implication of this view is that any kind of disparity between men and women should be viewed as discrimination, while the disparity between the rights and duties of men and women is in some cases a difference, not discrimination; And what is considered reprehensible and 
disgusting is undue discrimination, which is oppression and injustice. The existence of some differences and paying attention to them in the status of rights and duties is the same as justice, not oppression of women. Justice does not require that the rights of men and women be exactly the same, but rather that it oppresses men and women and ignores their abilities, differences and developmental characteristics. Any kind of difference should not be considered as discrimination, and equality between men and women in rights and duties should mean complete similarity between men and women in rights and duties, rather, equality means that each man and woman enjoys appropriate rights and duties according to their developmental characteristics and nothing is imposed on them. The different functions of men and women and the complementary role of the two for each other and the creation of balance in the system of existence make the differences between men and women in some rights and duties necessary, and this is justice, not oppression and discrimination to try to remove it. (Baqerzadeh, No. 7, 2009, p. 4).

In the Convention, equality means the annulment and disregard of the gender characteristics of men and women, ie the annulment of the masculinity and femininity of the two in order to achieve full similarity between men and women in rights and duties, whereas in the constitution of the Islamic Republic of Iran, which is regulated according to Islamic criteria, equality in the second meaning is willed; That is, every human being, both men and women, must have the appropriate and sufficient opportunities and backgrounds to grow and develop and reach existential perfections, and gender should not be an obstacle for any man or woman to achieve this sublime desire and whoever uses his opportunities better will achieve more growth and perfection and will be superior to the other.

\section{The age of marriage in the fifth goal of the 2030 UNESCO document and jurisprudence and law}

In this section, examples of conflict between the fifth goal of the 2030 UNESCO document in the field of gender equality from the perspective of jurisprudence and law are examined.

3-1-Age of marriage from the perspective of the 2030 document

At the international level, some conventions address the issue of the minimum age for marriage for children, including the Convention on the Elimination of All Forms of Discrimination against Women, the Convention on Consent Marriage, the Minimum Age for Marriage and the Registration of Marriages, and the Recommendation on consent to marriage, minimum age for marriage and marriage registration" and, of course, the "World Conference on Women in Beijing.

The Convention on consent marriage, the minimum age for marriage and the registration of marriages, adopted on November 7, 1962, does not specify a specific age for marriage, and article 2 obliges countries to take the necessary legal measures to determine the minimum age for marriage and no one under the age of marriage should be legally registered by any person.

The United Nations General Assembly in 1965, in a resolution entitled recommendation on marriage consent, reaffirmed the minimum age for marriage and the registration of marriages on 1 November 1965 in its second principle and states that the minimum age for marriage should not be less than 15 years; This is a logical criterion for determining the minimum age for marriage. Clause 2, article 16 of the Convention on the Elimination of All Forms of Discrimination against Women (adopted on 18 December 1979) declares child marriage to have no legal effect. This article states: "Child engagement and marriage have no legal effect, and all necessary measures, including the enactment of a law to determine the minimum age for marriage and the compulsion of marriage registration in official offices, must be taken".

\section{Age of marriage and permission of the householder from the perspective of jurisprudence and law}

All sects of Islamic jurisprudence consider minor marriage permissible by the householder. Among the Shiite jurists, no opposition has been mentioned, except Ibn Abi Aqeel, who opposes the householder (Al-Khoei, Bita vol. 2, p. 248).

And among the Sunnis, there are three people who are against the principle of prescribing, and they are: "Uthman al-Bati", "Ibn Shabrma" and "Ibn Hazm" (Abu Zohra, Bita p. 109). From this 
point of view, there is no verbal or rational reason that can be used normally and common to allow child marriage. Accordingly, it should be sufficient to a minimum.

Article 1041 of the civil law approved in 1313 states: "Female marriage is prohibited before reaching the age of 16 and male marriage before the age of 18 is prohibited, however, in cases where the interests require it, exceptions to the age requirement may be granted exceptionally upon the recommendation of the public prosecutor and the approval of the court; But in any case, this exemption cannot be given to females who are less than 13 years old and to males who are less than 15 years old". (Collection of Laws of 1934,p.85) Article 23 of the Family Protection Law, approved in 1974, Article 1041 is amended as follows: "It is forbidden for a woman to marry before the age of 18 and for a man to marry before the age of 20. However, in cases where the material requires, with the exception of a woman who is not less than 15 years of age and is physically and mentally healthy for married life, and exemption from the age requirement may be granted upon the recommendation of the prosecutor and with the approval of the city court. A woman or a man who marries a person who has not yet reached the legal age for marriage, contrary to the provisions of this article, will be sentenced to the punishments provided in Article 3 of the Marriage Law approved in 1937, as the case may be". In 1982, Article 1041 was amended and implemented experimentally for 5 years. The new amendment read: "Marriage before puberty is prohibited". "Note: Marriage before puberty with the permission of the householder is valid, provided that the financial interests of the defendant are observed". This amendment was finally approved in 1991 and was implemented definitively. This amendment is based on the famous fatwa of Imami jurists. The republic of Muslim jurists believe that in the marriage contract, the householder is one of the pillars of this contract and if the marriage takes place without his consent, this contract is void. This group believes: "If there is no householder, the wife cannot even read the contract itself. This vote is the opinion of the Shafi'i, Maliki and Hanbali jurists; "And this group has cited the following reasons to strengthen its vote": (Al-Bahouti, vol. Bita, p. 35; Al-Khatib al-Sherbini vol. Bita, p. 147, Ibn Qadameh Bita, p. 449; Al-Dardir, Bita.)

1) Quran: One of the reasons for this group of jurists is this Quranic verse which God says:

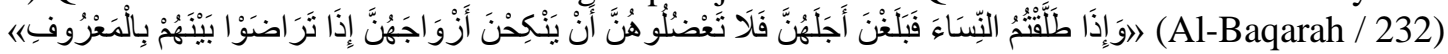
"Once you (the marriage) have divorced them and their period has expired, you should not forbid them from marrying, whenever they legally consent to marry a man". Imam Shafi'i says in this regard: In this verse, the meaning of householder over the wife at the time of marriage is so clear that it is not possible for this verse to have any other meaning.

2) Tradition: There are some hadiths narrated from the Prophet of Islam (PBUH) about the invalidity of marriage without the permission of the householder, and it is enough to mention a few of them here:

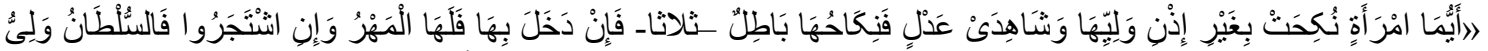

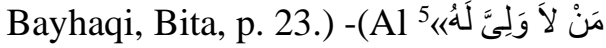

"Every woman who marries without her permission, her marriage is void - He repeated this sentence three times -So if he had intercourse with her, it is obligatory to pay the dowry for intercourse, so if they have a dispute, the sultan is the householder who has no householder". There is no ambiguity in the words of the Prophet and it is clearly stated that marriage without a householder is void. Of course, in a marriage without a householder, the prohibition of adultery is not obligatory on the husband ; Because due to the differences of the jurists about the validity or invalidity of marriage without the presence of a householder, suspicion has been created and as you know, it removes the suspicion of prohibition.

3) The third reason for this group is mostly related to the woman herself and the problems that may arise for her. This group believes that a woman has modesty and does not want to act in her own life without the permission of the householder. Also there are many problems in life, and marriage is important, and a woman cannot decide for herself. According to the arguments given, this group of jurists did not differentiate between being a virgin or a widow or a minor or a non-minor or not and verdict of annulment was not in case, but they have been generalized to all cases. There are two articles in Iranian civil law in this regard: 
A) Article 1043, according to which a virgin girl cannot marry without the permission of the householder. According to the article: "The marriage of a virgin girl, even if she has reached the age of puberty, is suspended with the permission of her father or paternal grandfather, and whenever the father or paternal grandfather bothers to give permission without a valid reason, his permission is revoked and in this case the daughter can fully introduce the man she wants to marry and the conditions of marriage and dowry that are placed between them after obtaining permission to go to the marriage registry from a special civil court and to register the marriage. Of course, if she makes excuses, the girl can get married in a special court by fully introducing the man she is interested in living with.

B) Article 1044 also deals with the lack of access to a householder who has given permission to a girl to marry him who marries without the permission of the householder. According to the article: "If the father or paternal grandfather is not present and it is usually impossible to get permission from them and the daughter needs to get married, she can get married.

Note: The registration of this marriage in the registry office is subject to the above cases in a special civil court."

In Article 1043, the marriage of a virgin girl, even if she has reached the age of puberty, is suspended with the permission of her father or paternal grandfather, and if the father or paternal grandparents refuses to give permission without a valid reason, her permission is revoked and in this case, the girl can go to the marriage registry office with the man she wants to marry and the terms of the marriage and the contract between them, after obtaining permission from the special civil court and to register the marriage.

\section{Divorce right}

\section{The right to divorce from the perspective of the 2030 document}

International documents emphasize the equal rights of men and women in divorce. According to paragraph 1 of Article 16 of the universal declaration of human rights: "Adult men and women, without any limitation as to race, nationality or religion, have the right to marry and to found a family. Everyone deserves and is entitled to equal rights at the time of marriage, during cohabitation and at the time of termination." Accordingly, men and women have the same right to marry and divorce.

2-3-The right to divorce from the perspective of jurisprudence and law

In jurisprudence, divorce is the valley of the husband (Nouri Tabarsi, 1993, p. 15306 and Horr Ameli, 1993,27 11 p. 223). However, in the following cases, a religious judge (court) can officially divorce a woman. Nowadays, this condition is called divorce in absentia:

A) Refusal or inability of the husband to pay alimony. If the husband is unable to pay alimony or refrains and the wife does not tolerate and complains to the court, the court can force the man to pay alimony and divorce the woman again if the husband has it. The following narration indicates this:

Imam Sadegh (AS) said: "If the husband gives enough to the wife of sufficient clothing and food (he has done his duty), otherwise leave a separateness between the two." (Horr Ameli, 1993, 27-11 p. 223)

2. Abu Basir Moradi says: I heard Imam Baqir (AS) say: "Whoever has a wife but has not provided her with clothes and food as much as he needs, the Imam has the right to separateness between the two." (Horr Ameli, Previous)

B) The long absence of the husband and not knowing about him. It is customary to recognize absence for a long time, although in jurisprudence this absence is set at 4 years. (Khomeini, 2005, vol. 2 p. 340)

C) Aser and Harj.

Aser and Harj is one of the jurisprudential rules that can be applied in marital relations. Marriage is a commitment and obligation for the couple, but if there are conditions that endure the cohabitation and its duration is very difficult and a lot of hardship for the wife in a way that is difficult to bear, the person will be in Aser and Harj.

D) Elai. Elai means a man who has swearing that has left intercourse with his wife for four months or more. There are narrations which say: In these circumstances, the ruler of Shari'a forces the husband to pay the ransom and swear and pay the atonement otherwise, by forcing or 
Examining the desired gender equality, the fifth goal of the UNESCO 2030 document, from the perspective of jurisprudence and law with emphasis on the age of marriage and the right to divorce

hardening the food, it will force him to divorce, and it is even sometimes stated (Horr Ameli, previous, vol. 15, pp. 535-547) in the narrations that due to disobedience to the ruling order, the husband is beheaded and regarding chapter 2 of the book "Explanation of Shiite means to study Sharia issues", states: 《فان ابي فرق بينهما الامـام)

That is, if the husband refuses, the Imam and the ruler of the Shari'a will separate between the two. (Hoor ${ }_{s}$ Ameli ${ }_{s}$ Previous, vol. 15, p)

Imam Khomeini (ra) has specified in several cases from his jurisprudential (Khomeini, vol. 2, 2005 , p. 340) arrangement and several times in the field of lectures and expressions of his political (Khomeini, vol. 10, Bita, p. 406) and social views, the possibility of divorce by the court and the judge of Sharia. All of these cases indicate the validity and possibility of divorce in absentia by a court or sharia judge, and all specify the fall of the right to divorce from the spouse. When in this case the "right to divorce" can be revoked from one spouse to another, it becomes clear that the revocation of this right from the spouse is "permissible and possible" in other cases as well.

A higher point than the "possibility of revoking the wife's right to divorce" is that today the couple's apparently has the power to divorce and the court has the power to divorce, because no man can divorce his wife without the court's permission.

According to Article 1133 of the Divorce Law, a man can divorce his wife at any time. However, in the following cases, the woman can request for divorce:

1. According to Article 1129 of the Civil Code: If the husband refuses to pay alimony and it is not possible to enforce the court ruling and he is obliged to pay alimony, the wife can refer to the governor for divorce and the husband will force the husband to divorce. It is also in case the husband is unable to pay alimony.

2. According to Article 1130 of the Civil Code: If the duration of the marriage causes Aser and Harj to the wife, she can refer to the governor of Sharia and request for divorce, if the Aser and Harj is proved in court, the court can force the husband to divorce, and if coercion is not possible, the wife will be divorced with the permission of the religious judge.

3. According to Article 1029 of the Civil Code: If a person has been absent for 4 years, his wife can file for divorce. In this case, in accordance with Article 1023, the governor divorces him. According to Article 1023 of the Divorce Law, the court publishes advertisements in local newspapers and one of Tehran's Kasir Ol Enteshar newspapers three times each, one month apart. If one year has elapsed from the date of the first announcement and the missing life is not proven, a hypothetical death sentence is issued against him.

4. Applying for a divorce decree using Article 1119 of the civil law; According to the mentioned legal article, the parties to the contract can fulfill any condition that is not contrary to the requirements of the said contract, in addition to the marriage contract or other necessary contract. For example, it is stipulated that if a husband marries another woman, or disappears for a certain period of time, or leaves alimony or commits an act or abuse against a woman's life that makes their lives unbearable with each other; The woman is a lawyer who, after proving the fulfillment of the condition in court and issuing the final verdict, divorce herself.

Article 1130 of the previous civil law adopted in 1314 listed three reasons for divorce at the request of the woman:

1. Cases in which the husband does not fulfill the other obligatory rights of the wife and it is not possible for her to comply.

2. Abuse of the husband, to the extent that the continuation of the wife's life with him is unbearable.

3. If marital survival is endangered for a woman due to incurable infectious diseases.

In this article, the legislator has stated the situations that can cause hardship and hardship to the wife, but has not explicitly mentioned the occurrence of Aser and Harj as the cause of divorce. Due to the necessity of personal actions in achieving Aser and Harj and also the nonconfinement of its examples, the status of the article in this way was not a solution. Until the Judicial Commission of the Majlis on 12/29/1982 tentatively amended it as follows and considered the prevention of harm as one of the common causes of divorce at the request of the woman:

In the following case, the woman can refer to the sharia governor and request a divorce. If it is 
proved to the court that the permanence of the marriage causes Aser and Harj, it can force the couple to divorce to prevent harm, and if it is not possible, divorce will be granted with the permission of the governor of Sharia. In this year, in addition to amending Article $1130 \mathrm{BC}$, conditions were also included in the official marriage contract, according to which the wife has been granted the right to divorce in twelve cases. The text of the marriage document was approved by the Supreme Judicial Council with the mentioned conditions and was notified to the State Document Registration Organization on 9/19/1983. The above conditions, which are almost similar to the restricted cases, if any of them are fulfilled, they will divorce themselves by referring to the court and obtaining a permit after choosing the type of divorce.

Finally, the mentioned plan was proposed and approved in the parliament on 2000.

Single Article: A note as follows was added to Article 11130 BC approved on 11/5/1991:

Note: The Aser and Harj of the subject of this article is:

The emergence of a situation that makes the continuation of life difficult for the wife and difficult to bear, and the following cases, if found by a competent court, are examples of Aser and Harj:

1. Deliberate abandonment of the spouse by the couple for at least 6 months without a valid excuse.

2. Harmful addiction to one of the types of drugs.

3. Refusal to pay alimony and his inability to pay alimony.

4. Infection of the couple with incurable infectious diseases or any other complication that endangers the marital survival and health of the wife.

5. The infertility of the husband in a way that prevents the wife from having children, such as drug trafficking and vagrancy.

6. Abuse and association of the husband to the extent that mystics are not tolerable for the wife in terms of space and time in terms of social, moral and spiritual interests.

7. The authority of the other spouse in case of inability to administer justice.

8. Failure to comply with a court order prohibiting employment or occupation that is contrary to the interests of the family or the dignity of the wife.

9. Definitive conviction of the wife to imprisonment as a result of committing crimes that are contrary to the family status and status of the wife.

In July 2000, the Guardian Council declared the remark illegal. By arguing that the above examples are not objective examples applicable to all people at any time and place. Rather, the combination of some of these titles with other conditions causes fault. In addition, in any situation, these examples cannot be considered a real example of fault. Because sometimes none of these characteristics exist for a person, but in fact he makes a mistake and sometimes vice versa. Therefore, the mentioned titles are not an example of fault and it cannot be explicitly said that; if one of these titles arises in married life, it is a mistake, but it depends on the circumstances. Care in defining this word will clarify the issue.

The cases mentioned in this article do not prevent the court from issuing a divorce decree in other cases where the woman is in Aser and Harj.

Additional note to Article $1130 \mathrm{BC}$. As it is a guide for the judge and to some extent prevents the dispersal of votes and the undermining of women's rights, and also, in order to eliminate duplicate cases, such as the couple refusing to pay alimony and the impossibility of being obliged to pay, the duty of this case is specified in Article 1129 BC, and addressing the wrong issues with other diseases is in the way of protecting the rights of women for whom the continuation of married life is unbearable.

\section{Discussion}

In international documents and their interpretations state that the child enters the field of social issues and responsibility at the age of eighteen; Whereas in Islamic jurisprudence, the age of a boy is 15 lunar years and in the age of a girl there is a difference of fatwa which means that he is 9 years old; Thirteen years old and normal puberty. According to a note in Article 1210 of the civil law, there is a difference between the age of puberty of a girl and a boy. According to Article 49 of the Islamic penal law, children are exempt from criminal liability, but according to 
Examining the desired gender equality, the fifth goal of the UNESCO 2030 document, from the perspective of jurisprudence and law with emphasis on the age of marriage and the right to divorce

international law, the age of juvenile responsibility is 18 years. The marriage of a virgin girl is subject to the consent of the father, and of course his consent is a condition for the influence of the marriage. This authority belongs only to the father, and it does not have such a restriction only in the case of a virgin daughter and a son; As a result, there is a difference between parents and sons and daughters. This situation can cause serious problems for the girls, but in any case, it is in their best interest not to act without the consent of the father. Of course, in cases where the father abuses this right, there are solutions to prevent it. This provision is in conflict with Articles 1,151 and 16 of the convention forbidding discrimination against women. In addition, as a basic principle, the ruling on divorce is considered in the possession of the man and part of his legal capabilities, and only in special and exceptional cases, the woman can free herself from the shackles of marriage. This is certainly not in line with Articles 1 and 16 of the Convention.

\section{Conclusion}

In reviewing the 2030 document as a whole, the dominant view in drawing development ideals is a global one, and disregard for regional development and cultural specificity is one of its fundamental gaps. In principle, the acceptance of such documents is not acceptable by any religious logic. The minimum requirement for the acceptance of such international documents is the acceptance of the legitimacy of international institutions in formulating macro principles and policies for the Islamic system based on their secular foundations.

\section{References}

Abu Zohra, Muhammad. (2000). Al-Ahwal Al-Shakasiya, (Third: Dar al-Fikr, Beirut).

Al-Bahouti, Mansour Ibn Yunus Ibn Idris. (2002). Al-Rawd Al-Muba'ah Sharh Zad AlMustaqnah, volan publisher.

Al-Bayhaqi, Abu Bakr Ahmad Ibn Ali. (1999). Al-Sunan Al-Kubra, vol. 7, Beirut, Dar al-Kitab al-Alamiya.

Al-Dardir, Abu al-Barakat Ahmad ibn Muhammad Ahmad,. (1990). Aqrab al-Masalak for the religion of Imam Malik, Ayub Kano School of Nigeria.

Al-Khatib al-Sherbini, Shams al-Din Muhammad ibn Ahmad. (2009). The needy to know the meanings of the words of the curve, $\mathrm{C} 3$, Beirut, Dar al-Ma'rifah.

Al-Khoei, Abu al-Qasim. (2001). documentary Al-Urwa Al-Wathqi, Kitab al-Nikah, (Dar AlAlam School Press, Qom).

Bagherzadeh, Mohammad Reza. (2009). "A Look at Women's Rights in Islam, A Critique of the Convention on the Elimination of All Forms of Discrimination against Women". Maaref Quarterly, 7, 90-110.

Emami, Hassan. (2007). Civil Law, Islamic Bookstore, Fourth Edition,.

General Department of Laws of the Islamic Consultative Assembly. (1985). Detailed Report of the Debates of the Assembly, Final Review of the Constitution of the Islamic Republic of Iran. Islamic Consultative Assembly, 1(31), 120-134.

Hoor Ameli, Muhammad ibn Hasna. (1993). detail of Shiite means to study Sharia issues, vols. 11 and 27, Qom: Al-Bayt (AS) Institute for the Revival of Heritage, Second Edition, (30 volumes).

Jafari, Mohammad Taghi. (1987). Interpretation and Criticism and Analysis of Masnavi, Volume 1, Islamic Publications.

Jeffrey, Sachs. (2005). United Nations Millennium Project, 2005; Investment in development; Practical plans for achieving development goals, Hazara, Translators Group, Tehran, 


\section{Barghe Zeytoon.}

Khomeini, Ruhollah. (2005). Tahrir al-Wasileh, vol. 2, Tehran, Imam Khomeini Publishing House.

Motahari, Morteza. (1992). The system of women's rights in Islam, Tehran: Sadra Publications.

Nouri Tabarsi, Hussein. (1987). Mustadrak al-Wasa'il, vol. 15, second edition, Beirut: Al-Bayt (AS) Foundation for the Revival of Heritage.

Qaraati, Mohsen. (2009). Tafsir Noor (10 volumes), Cultural Center of Lessons from the Quran, Tehran, Vol. 7. 